\title{
Development of Educational Program for Production Managers Based on a Symbiotic Competition with ABC-G Network
}

\author{
Masahiko Ishihara*, Makoto Nakano, Kazuyoshi Ishii \\ Department of Management Systems, Kanazawa Institute of Technology, Ishikawa, Japan
}

(Received: January 25, 2014 / Revised: May 26, 2014 / Accepted: August 6, 2014)

\begin{abstract}
This paper proposes a management system for the educational program of production managers on the basis of value co-creation by the learner and the instructor. The program combines an intelligent knowledge-based approach with the kaizen activity program. The program helps individuals acquire knowledge and skills to ensure the total rather than the partial optimization of processes and operations facilitating continuous improvement in the workplace. To achieve these goals, the program uses models of a learning process and a swing of enlightenment. In addition, the program is supported by a framework of academic, business people, consultants, and government officers. The program was developed using an instructional design approach. This paper discusses the process of developing and managing the educational program between 2006 and 2012 as well as the results obtained.
\end{abstract}

Keywords: Educational Program, Value Co-creation, Symbiotic Competition, Production Manager

*Corresponding Author, E-mail: masa_ishihara@neptune.kanazawa-it.ac.jp

\section{INTRODUCTION}

In the history of standardization, the start of the 20th century was a significant time for human-kind. In 1911, Taylor (1911) published The Principles of Scientific Management which presented a very efficient management system. This system was based on Smith (1789) who proposed the division of labor to realize the principle of specialization and thus simplification. Taylor reinforced this with the concept of standardization, and division of planning and controlling functions (Spender and Kijne, 1996). In this way, standardization, a concept applied to objects (hardware) since Whitney in the late 18th century, was extended to tasks (software). Henry Ford is notable for having successfully applied this system to business, developing a production system based on a single-product assembly line that maximized production quantity under a certain level of investment. Similar ma- nagement system schemes have spread worldwide. The study and implementation of this approach in Japan led to company-wide management activities uniquely tailored to Japanese culture. Examples include companywide (or total) quality control (CWQC or TQC) (Mizuno, 1969), total productive maintenance (TPM) (Japan Institute of Plant Maintenance, 1996), and just-in-time (JIT) production (Sugimori et al., 1977). These approaches brought Japanese companies to the forefront of international business in the late 20th century. Companywide kaizen (continuous improvement) activities were based in spirit on the work simplification program developed by Mogensen (1932). The fruit of the Industrial Revolution was optimal allocation of management resources under limited natural resources to create useful products and services. Scientific management made great contributions towards such value maximization. It is called 'economies of scales.' Since the middle of the 20th 
century, progress in information and communication technology (ICT) promoted the development of many useful management tools for production. Examples include manufacturing requirement planning (MRP II), Enterprise Resource Planning (ERP), software packages for supply-chain management system, customer satisfaction management, and customer relationship management (Sheikh, 2003). Efficient management systems reflect Adam Smith's insight that producers must innovate and improve production systems to keep their competitive advantages and to maintain market shares. This revolution has also promoted the global sharing of information and knowledge.

The 21 st century is characterized by ubiquitous networking with the potential to realize a society where everyone has equal access to crucial information and knowledge (Paine, 2003; Toffler and Toffler, 2006). This means that companies can collaborate to deliver products and services that customers' most highly value. Drucker (1993) pointed out that scientific management has contributed to drastic productivity increases by applying knowledge to industrial activity, and that knowledge has become a more important management resource than the tangible assets, such as currencies, machinery, real estate, inventories, equipment. He also pointed out that the problem in management of the future will be how to improve productivity in applying knowledge to create new knowledge, which will in turn be applied to developing new products, services, and innovation. Knowledge as an intangible management resource is qualitatively different from tangible resources, in that knowledge does not decrease when shared. The 21 st century presents an era of new value creation on the basis of symbiotic competition (Brandenburger and Nalebuff, 1996; Inose, 2000), in which mutual understanding and knowledge sharing are optimized through the information networks in the relationships between suppliers and customers, expert and novice as well as teacher and student (Prahalad and Ramaswamy, 2004; Seybold et al., 2001; Toffler and Toffler, 2006). In such a society, knowledge creation will be an important competitive edge for companies in global markets (Nonaka and Takeuchi, 1995).

The discussion about the changes in the turn of the century is summarized in Table 1.

This paper proposes a management system for an educational program for manufacturing managers who are making contributions toward the use of manufacturing technology for the creation of exceptional customer satisfaction. The program combines an intelligent knowledge-based approach with the kaizen activity program that promotes knowledge creation by means of learning through self- and mutual-enlightenment. The developed program is supported by a framework of academic (A), business people (B), consultants $(\mathrm{C})$, and government officers $(\mathrm{G})$. It is called an ABC-G network. The goal of the program is to help such individuals acquire knowledge and skills to ensure total optimization instead of partial optimization of all business processes and operations, and to facilitate continuous improvement in the workplace. The paper also discusses the process and results of the development and management of this educational program from 2006 to 2012 .

To achieve the aims mentioned above, the following research questions are discussed in this paper.

1) How to build a model behind this research?

2) How to develop an effective educational management system for production managers who can improve continuously the outcomes of the educational program to satisfy the needs of the stakeholders?

3) How to evaluate the educational program and the management system and to identify the problem for a continuous improvement of the program and system?

4) What are the implemented results of the program?

\section{MODEL CONSTRUCTION AND DESCRIPTION}

\subsection{Learning Process Model}

Taylor (1911) emphasized vertical specialization to improve productivity meaning the division of knowledge into two categories: knowledge of work planning and that of implementation. This restriction of scientific management for knowledge sharing and creation may be solved in a practical way by kaizen activities in Japan. Based on the discussion above, the learning process model shown in Figure 1 is proposed.

In this figure, learning involves knowledge acquisition, understanding and creation. Also, knowledge is classified into explicit and tacit as a foundation (Polanyi

Table 1. The changes of the trend of era

\begin{tabular}{lll}
\hline \multicolumn{1}{c}{ Factor } & \multicolumn{1}{c}{$\begin{array}{c}\text { Industrial society } \\
\text { (20th century) }\end{array}$} & \multicolumn{1}{c}{$\begin{array}{c}\text { Knowledge society } \\
\text { (21st century) }\end{array}$} \\
\hline Main management resource & Tangible assets (fixed and current assets) $)$ & Intangible assets (intellectual asset) \\
\hline \multirow{3}{*}{ Economic driver } & $\begin{array}{l}\text { Competition based on economic } \\
\text { efficiency }\end{array}$ & $\begin{array}{l}\text { 'Co-opetition' [13] based on a symbiotic competition } \\
\text { (value co-creation) }\end{array}$ \\
\cline { 2 - 3 } & $\begin{array}{l}\text { Economies of scales (minimizing the } \\
\text { fixed cost per a product) }\end{array}$ & Maximizing the through put (marginal profit) \\
\hline Relation between stakeholders & Teacher $\rightarrow$ Student & Teacher $\longleftarrow$ Student \\
\hline
\end{tabular}




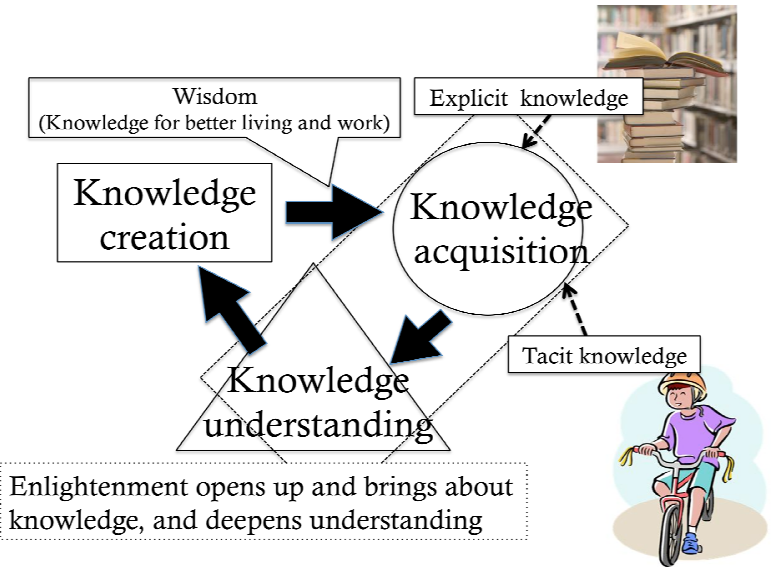

Figure 1. Learning process model.

and Sen, 1967). Although explicit knowledge is factual and objective, tacit knowledge is unarticulated, subjective, and context specific (Malhotra, 2000).

\subsection{Swing Model for Two Kinds of Enlightenment and a Model of Strength of Feeling}

Kaizen is a never-ending activity. Learning also has a similar characteristic. To manage both educational programs must pay attention to the relation between the inspiration and actions of learners. Inspiration induces action. Individuals who are inspired by certain information or events usually take action to maximize their experience, which gives them further inspiration. This process can be likened to the swing of a pendulum between inspiration and action. A pendulum that begins to swing inside an individual often induces swing phenomena in other individuals as well, which eventually develops into a chain of swing phenomena (Figure 2), indicating a broad acceptance process. The swing phenomenon itself can be considered as a process of self-enlightenment. A series of swing phenomena interacting with and amplifying one another represents the process of mutual-enlightenment. Understanding the factors inducing the swing phenomena may be a key to maximizing both the psychological value and outcome and performance of learners.

It is pointed out in the psychological field that the type of feeling is classified to two types depending on the difference of its characteristic (Aikawa, 2012). That is emotion and mood which are shown in Figure 3. The emotions have a high strength of feeling in a short time at the early stage of a response by a specific stimulus. On the other hand, moods continue in the low strength of feeling for a long time after the occurrence of emotions. And the emotions have two kinds of the feelings. That is pleasantness and unpleasantness. In other words, a mood is an emotional state. Moods differ from emotions in that they are less specific, less intense, and less likely to be triggered by a particular stimulus or event. If the intentional stimulation which can hit a pleasant emotion of the learner is identified, the instructor should de-

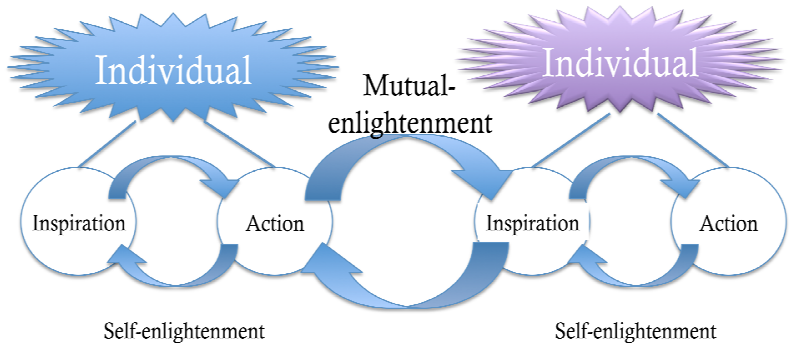

Figure 2. Swing model of the two kinds of enlightenment.

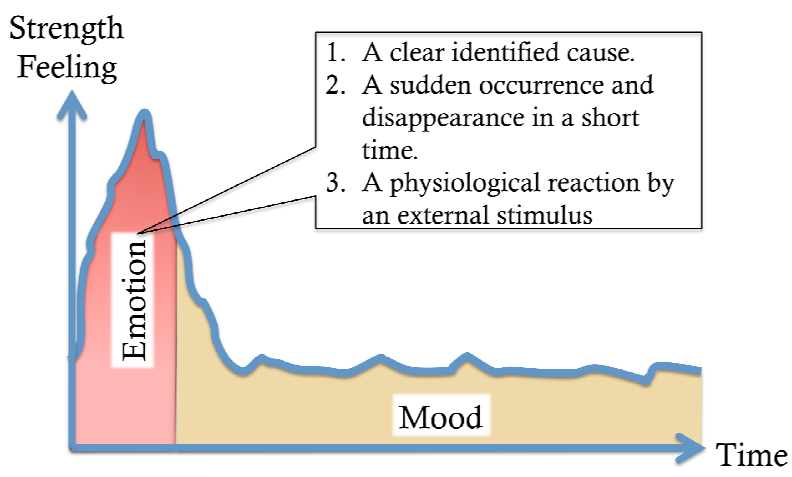

Figure 3. Model of a strength of feeling (Malhotra, 2012).

vise a way which makes the learner transform from the emotion to an action within a short time. Because an emotion disappears in a short time. This comes from 'Strike while the iron is hot.' If an educational program is developed on the basis of the feeling model shown in Figure 3 and the swing model for two kinds of enlightenment shown in Figure 2, an effect of the program on reinforcement of value co-creation (Payne et al., 2008) between a learner and instructor will increase.

\subsection{Fusion Model of Organizational and Individual Learning}

This model shown in Figure 4, is based on the management cycle model, value model, and kaizen activity program model. The management cycle model is from scientific management, and its process consists of plan, do, and check/action.

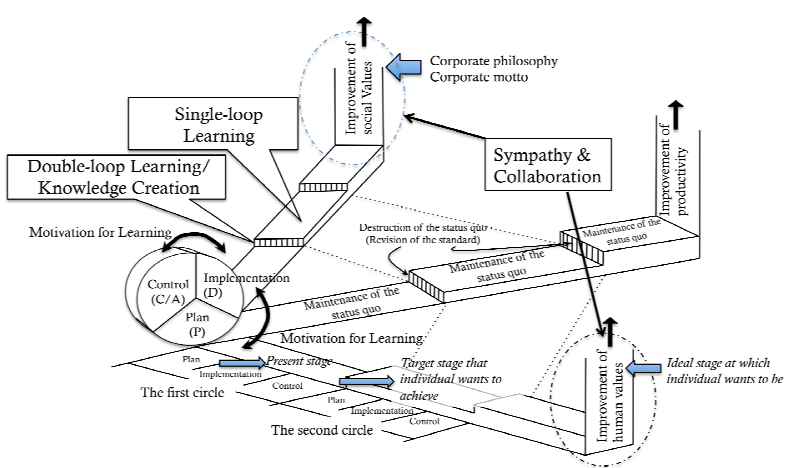

Figure 4. Learning process model for value co-creation. 
The value model has two kinds of values, social and individual. Efficiency, such as productivity, was the value predominantly focused on in the 20th century. Each organization has its own mission, vision and philosophy as a social value. At the same time, individuals have their own dreams and visions as human values. If the two kinds of value can be synchronized through education and learning activities, the possibility of collaboration with the creation of human value and the creation of social value will increase.

Kaizen includes two kinds of activities: disrupting the status quo to improve value and maintaining the results obtained from such disruption. Knowledge creation is required when disrupting the status quo and establishing new operations, organizations or systems. At the same time, there is risk and resistance to change and reform. Learning requires different approaches according to the type of kaizen activities, namely single-loop learning and double-loop learning (Argyris, 1999). In repeating the management cycle of kaizen activity and learning, four stages of value are identified - present stage, the ideal stage, the target stage, and the implementation stage.

\subsection{Instructional Design and the ADDIE Model}

The ICT revolution has brought great changes to education and learning. The spread of the Internet has made information ubiquitous, changing the emphasis of education from the transmission and acquisition of knowledge to knowledge creation (Toffler and Toffler, 2006), and shifting the focus from group to individual education. Also, the discussion of education systems is moving from instructor to learner (Piskurich, 1993; Seybold et al., 2001). Although there is a great impact of ICT on education and learning system, the effects of educational psychology and educational technology cannot be ignored. This field overall is referred to as instructional design (ID) (Ryder, 2014). ID process models are generally divided into the two categories: Analysis, Design, Development, Implementation, and Evaluation (ADDIE) model (Rothwell and Kazanas, 1998) and rapid prototyping models (Allen, 2003; Piskurich, 2000). Rapid prototyping models are based on ADDIE models. ADDIE models are general models for the management of ID, and hold ID activities as processes of Analysis, Design, Development, Implementation and Evaluation. This model is based on the management cycle model. Table 2 shows the relationship between ADDIE and 'plan-docheck-act' (PDCA) models (Ishii and Tamaki, 2009).

\section{PROCESS AND RESULTS OF THE CASE STUDY}

\subsection{Outline of the Development Process}

This research and development project is aimed at human resource development and at managing the development of technology for knowledge and skill transfer. The Japanese Ministry of Economy, Trade and In-

Table 2. ADDIE model of ID and the management cycle

\begin{tabular}{|c|c|c|c|}
\hline $\begin{array}{l}\text { Management } \\
\text { Cycle }\end{array}$ & ADDIE model & & Operations and methods \\
\hline \multirow{10}{*}{ Plan } & \multirow{3}{*}{ Analysis } & \multicolumn{2}{|l|}{ Needs analysis } \\
\hline & & \multicolumn{2}{|l|}{ Job analysis } \\
\hline & & \multicolumn{2}{|l|}{ Student analysis } \\
\hline & \multirow{5}{*}{ Design } & \multicolumn{2}{|c|}{ Setting learning goals (target behaviors, evaluation conditions, achievement levels) } \\
\hline & & Structuring & \multirow{2}{*}{ Determination of learning contents (knowledge, skills, values) } \\
\hline & & Sequencing & \\
\hline & & \multirow[t]{2}{*}{ Programming } & Determination of learning methods considering student characteristics \\
\hline & & & $\begin{array}{l}\text { Determination of provision methods (joint training/individual training) } \\
\times(\text { cost performance })\end{array}$ \\
\hline & \multirow{2}{*}{ Development } & \multicolumn{2}{|l|}{ Textbooks } \\
\hline & & \multicolumn{2}{|c|}{ Multimedia materials (in-house of consigned development) audiovisual + interactive } \\
\hline \multirow{2}{*}{ Do } & \multirow{2}{*}{ Implementation } & Tutoring & \\
\hline & & Mentoring & \\
\hline \multirow{4}{*}{$\begin{array}{l}\text { Check/Action } \\
\quad \text { (See) }\end{array}$} & \multirow{4}{*}{ Evaluation } & \multirow{2}{*}{ Evaluation subject } & Learner \\
\hline & & & Program \\
\hline & & \multirow{2}{*}{ Evaluation method } & Formative evaluations + comprehensive evaluations \\
\hline & & & Reaction/Learning/Behavior/Results \\
\hline
\end{tabular}

ADDIE: Analysis, Design, Development, Implementation, and Evaluation, ID: instructional design. 
dustry sponsored this project from 2005 to 2006, and Ishikawa prefecture sponsored it in 2007. Since 2008, Kanazawa Institute of Technology has organized and managed the project as part of the curriculum for its master's degree in management engineering. Table 3 shows an overview of the process and results of developing the program based on the ADDIE model.

\subsubsection{Analysis process}

A questionnaire was distributed among 500 manufacturers in the region with more than 10 employees. Also, several interviews were conducted with excutives and person managers to understand the needs regarding education. The questionnaire response was $31.8 \%$. Analysis of the collected data indicated the need for developing the educational program.

\subsubsection{Design process}

Figure 5 shows the targeted participants, competencies reinforced by the program, the structure of the program and course objectives. Manufacturers in the Hokuriku region of Japan have distinct competitive edge in manufacturing technology, so the aim of the educational program was to develop human resources who could produce more customized, value-added products with shorter lead times and at lower cost. The targeted participants were managers employed by small- and mediumsized manufacturers of industrial machinery in the region. Competencies reinforced by the program were as follows:

1) Manufacturing higher quality products and services.

2) Critical thinking regarding what needs to be done to ensure growth of the organization and developing systems and tools for solving problems.

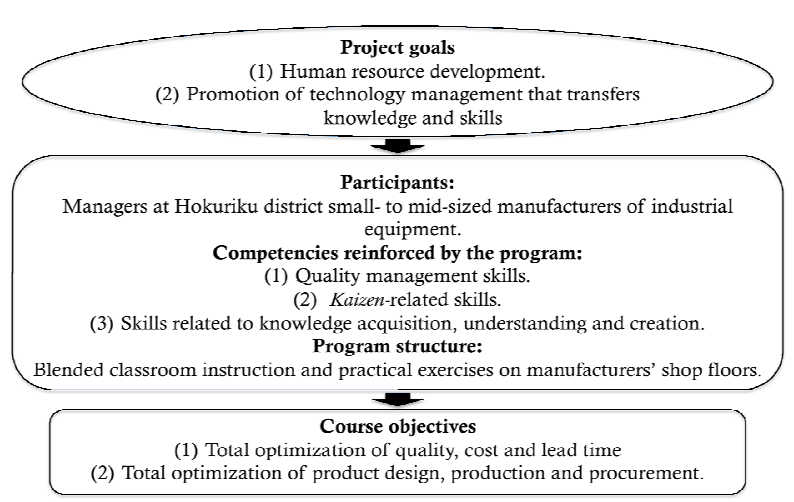

Figure 5. The flow in determination of course objectives.

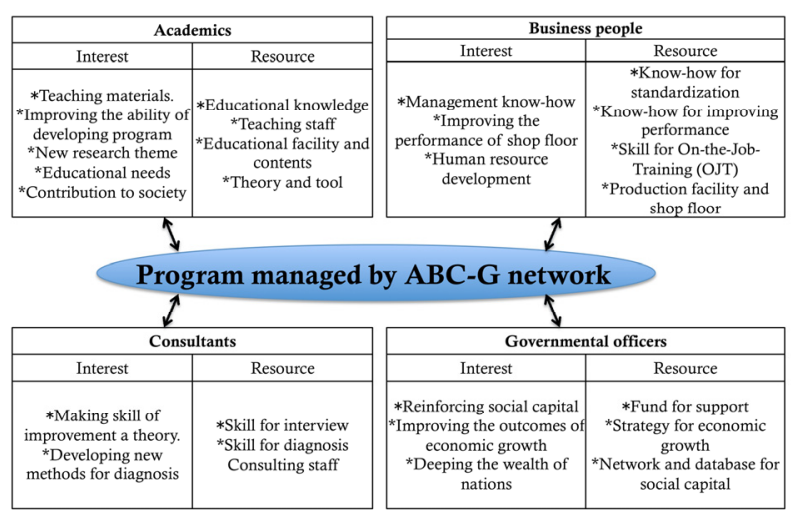

Figure 6. ABC-G network for symbiotic competition.

3) Acquiring, understanding and creating knowledge for (1) and (2) above.

The competencies were deployed in three courses developed under these objectives. Namely, to acquire the

Table 3. Outline of developing the program

\begin{tabular}{|c|c|}
\hline ADDIE model & Main results \\
\hline Analysis & $\begin{array}{l}\text { 1. } 99 \% \text { of all companies in the Hokuriku region are small or mid-sized companies. } \\
\text { 2. Main competencies required in production managers: } \\
* \text { Management skills related to quality, and cost control, and optimization of quality, cost and delivery. } \\
\text { * Computer literacy spreadsheets, 3D design tool, product data management and database. } \\
\text { * Skills related to process design, kaizen activity, and procurement. }\end{array}$ \\
\hline Design & $\begin{array}{l}\text { 1. Participants were company managers and KIT master's course students. } \\
\text { 2. Group work was performed between the managers and students. } \\
\text { 3. Learning was through a combination of classroom instruction and practical exercises. }\end{array}$ \\
\hline Development & $\begin{array}{l}\text { 1. Three textbooks were used, each available in printed and online form. } \\
\text { 2. Learners used IT Jigs from ICT technology as an educational tool. }\end{array}$ \\
\hline Implementation & $\begin{array}{l}\text { 1. Collaboration between learners and instructors. } \\
\text { 2. E-mail communications. } \\
\text { 3. A web-based evaluation system was used at each step of the program. }\end{array}$ \\
\hline \multirow[b]{2}{*}{ Evaluation } & Learner $\quad$ The intended learning outcomes of each course. \\
\hline & $\begin{array}{ll} & \text { 1. Evaluation by participants, hosts and participant supervisors. } \\
\text { Program } & \text { 2. Evaluation before, during and after the program. }\end{array}$ \\
\hline
\end{tabular}

ADDIE: Analysis, Design, Development, Implementation, and Evaluation, KIT: Kanazawa Institute of Technology, ICT: information and communication technology. 
ability to standardize and improve the problems, which were total optimization of not only multi-performance measures but also multi-processes under a make-to-order manufacturing system. The performance measures were focused on quality, cost, and lead-time. The multi-processes were product design, production, and procurement. In structuring the program, effective combinations of classroom instruction and practical exercises in the shop floor of manufacturers were discussed. An industrial machinery manufacturer in the Hokuriku region took part in a practical shop floor exercises. This blending method (Bersin, 2004) was one of key factors for program success. ABC-G network played an important role shown in Figure 6.

\subsubsection{Development process}

Textbooks were classified into three types: lectures, seminars and experiments, and practical exercises. IT Jigs (Ishii and Nkano, 2009) were developed for acquiring practical knowledge of decision-making procedures, and for learner understanding and knowledge creation through easy icon-based. This approach uses three types of bills of materials, three master files, a layout editor, a loading analyzer, and an flexible manufacturing system simulator.

\subsubsection{Implementation process}

On the basis of the swing model and learning process model shown in Figures 2 and 3, many methods and operations were proposed and implemented by instructors and learners to promote self- and mutual-enlightenment. This trial and error method continues today through emails between instructors and learners through the evaluation Web system for each step of the program.

\subsubsection{Evaluation process}

Learners were evaluated by the intended learning outcomes of each course. Programs were evaluated by three kinds of program stakeholder, the participant, the company hosting the practical exercise sessions, and the participants' supervisors who dispatch for the course. Participants performed evaluations before, during, and after the program. The company hosting the practical exercise performed an evaluation only after program completion. The participants' supervisors performed evaluations before and after the program.

\subsection{Results and Discussions}

\subsubsection{Evaluation of the program developed}

Three courses were designed as result of development, for quality management (QM), manufacturing knowhow and creativity (MKC), and knowledge chain management (KCM). Tables 4 and 5 give some of the results for participants' supervisor of KCM.

The values in Table 4 indicate supervisor expectations regarding the intended learning outcomes. Table 5 shows supervisor satisfaction regarding participant attitude and job performance at least 3 months after course completion.

Table 4 shows that the expectation level of each outcome of KCM varies over the past 7 years. This may be due to a lack of communication between the program managers and the participant supervisors about the competencies of total optimization of multi-process. On the other hand, Table 5 indicates that the item 'improved enthusiasm and commitment to fulfill their responsibilities at work' stayed at a very high level over the past 3 years except understanding. The similar evaluation re-

Table 4. Course objective and student goals of knowledge chain management

\begin{tabular}{|c|c|c|c|c|c|c|c|c|}
\hline \multirow[b]{2}{*}{ Course objective } & \multirow[b]{2}{*}{ Intended learning outcomes } & \multicolumn{7}{|c|}{ Year (response rate) } \\
\hline & & $\begin{array}{l}2006 \\
(50)\end{array}$ & $\begin{array}{r}2007 \\
(50)\end{array}$ & $\begin{array}{c}2008 \\
(10)\end{array}$ & $\begin{array}{l}2009 \\
(56)\end{array}$ & $\begin{array}{l}2010 \\
(86)\end{array}$ & $\begin{array}{l}2011 \\
(80)\end{array}$ & $\begin{array}{l}2012 \\
(33)\end{array}$ \\
\hline \multirow{5}{*}{$\begin{array}{l}\text { Have a clear understanding } \\
\text { of the processes involved in } \\
\text { creating products that meet } \\
\text { customer needs and acquire } \\
\text { the ability to standardize } \\
\text { and improve these } \\
\text { processes while taking into } \\
\text { consideration the cost and } \\
\text { delivery time. }\end{array}$} & $\begin{array}{l}\text { Capable of achieving standardization } \\
\text { and improvement in drawing control. }\end{array}$ & 43 & 0 & 100 & 20 & 100 & 50 & 0 \\
\hline & $\begin{array}{l}\text { Capable of achieving standardization } \\
\text { and improvement in process control. }\end{array}$ & 100 & 60 & 100 & 40 & 67 & 100 & 100 \\
\hline & $\begin{array}{l}\text { Capable of achieving standardization } \\
\text { and improvement in purchasing and } \\
\text { subcontract management. }\end{array}$ & 58 & 40 & 100 & 60 & 40 & 67 & 100 \\
\hline & $\begin{array}{l}\text { Capable of achieving standardization } \\
\text { and improvement in cost management. }\end{array}$ & 58 & 60 & 100 & 80 & 100 & 100 & 100 \\
\hline & $\begin{array}{l}\text { Capable of suggesting how } \\
\text { standardization and improvement can } \\
\text { be achieved in the above-mentioned } \\
\text { management activities from the } \\
\text { perspective of profit control. }\end{array}$ & 43 & 40 & 100 & 40 & 100 & 100 & 100 \\
\hline
\end{tabular}

Values are presented as percentage $(\%)$. 
sulted in the case of 'current tasks' of the potential for improved performance at work. But the result of 'improved behavior' changes year by year.

Table 6 shows the results of the questionnaire survey to the course participants. It shows that almost all participants have thought provided teaching materials appropriate, understood and satisfied them, although they have not many interests before the start of the course. The less interest with the course may be due to a lack of communication among participants, participants' super- visors and educational program managers.

Table 7 shows responses from teachers at the factories hosting the practical exercises. As shown in Table 7, the evaluation by the instructor of the hosting factory changes year by year. These results point out the further problem to take a continuous improvement of the educational program. Also, the outcomes of both of motivation for Kaizen activities to the factories, and benefit to the companies hosting the practical exercises have influence upon willingness to host the sessions again in the

Table 5. Improvement observed in the participants by their supervisors after course completion

\begin{tabular}{cccccccc}
\hline \multirow{2}{*}{$\begin{array}{c}\text { Year (re- } \\
\text { sponse rate) }\end{array}$} & $\begin{array}{c}\text { Improved enthusiasm and commitment to } \\
\text { fulfil their responsibilities at work }\end{array}$ & \multicolumn{2}{c}{ Improved behaviour } & \multicolumn{2}{c}{$\begin{array}{c}\text { Potential for improved } \\
\text { performance at work }\end{array}$} \\
\cline { 2 - 8 } & $\begin{array}{c}\text { Logical } \\
\text { thinking }\end{array}$ & $\begin{array}{c}\text { Under- } \\
\text { standing }\end{array}$ & $\begin{array}{c}\text { Willingness } \\
\text { to try }\end{array}$ & Communication & $\begin{array}{c}\text { Willingness to make } \\
\text { suggestions }\end{array}$ & $\begin{array}{c}\text { Current } \\
\text { tasks }\end{array}$ & $\begin{array}{c}\text { New } \\
\text { tasks }\end{array}$ \\
\hline $2006(50)$ & 90 & 87 & 87 & 67 & 78 & 100 & 100 \\
$2007(50)$ & 80 & 100 & 80 & 60 & 80 & 80 & 100 \\
$2008(10)$ & 100 & 0 & 0 & 100 & 100 & 100 & 100 \\
$2009(56)$ & 100 & 100 & 80 & 80 & 80 & 100 & 100 \\
$2010(86)$ & 100 & 100 & 100 & 67 & 67 & 100 & 67 \\
$2011(80)$ & 100 & 100 & 100 & 75 & 100 & 100 & 100 \\
$2012(33)$ & 100 & 50 & 100 & 50 & 100 & 100 & 100 \\
\hline
\end{tabular}

Values are presented as percentage $(\%)$.

Percentage of respondents indicating either 'greatly improved (or expected to improve greatly)' or 'improved.'

Table 6. Questionnaire survey of course participants after the completion of the course

\begin{tabular}{ccccc}
\hline $\begin{array}{c}\text { Year } \\
\text { (response rate) }\end{array}$ & $\begin{array}{c}\text { Very interested before the start } \\
\text { of the course }\end{array}$ & $\begin{array}{c}\text { Appropriate teaching } \\
\text { materials }\end{array}$ & Understood & Satisfied \\
\hline $2006(100)$ & 93 & 100 & 93 & 93 \\
$2007(86)$ & 100 & 100 & 92 & 92 \\
$2008(90)$ & 67 & 75 & 89 & 100 \\
$2009(92)$ & 83 & 100 & 92 & 100 \\
$2010(100)$ & 67 & 100 & 91 & 90 \\
$2011(67)$ & 67 & 100 & 100 & 100 \\
$2012(67)$ & 50 & 100 & 100 & 100 \\
\hline
\end{tabular}

Values are presented as percentage $(\%)$.

Very interesting + Interesting; Understood very well + Understood; Appropriate + Somewhat appropriate; Satisfied + Somewhat satisfied.

Table 7. Level of satisfaction of the individuals at the factories hosting the training sessions

\begin{tabular}{lccc}
\hline $\begin{array}{c}\text { Year } \\
\text { (response rate) }\end{array}$ & $\begin{array}{c}\text { Motivation for Kaizen activities to the factories } \\
\text { where the practical exercises were held \#1 }\end{array}$ & $\begin{array}{c}\text { Benefit to the companies hosting } \\
\text { the practical exercises \#2 }\end{array}$ & $\begin{array}{c}\text { Willingness to host the sessions } \\
\text { again in the future \#3 }\end{array}$ \\
\hline $2006(100)$ & 62 & 87 & 62 \\
$2007(67)$ & 50 & 100 & 100 \\
$2008(67)$ & 0 & 50 & 100 \\
$2009(100)$ & 67 & 67 & 33 \\
$2010(100)$ & 67 & 100 & 67 \\
$2011(67)$ & 50 & 100 & 50 \\
$2012(100)$ & 50 & 50 & 0 \\
\hline
\end{tabular}

Values are presented as percentage $(\%)$.

\#1: Percentage of respondents selecting either 'Very large advantage' or 'Fairly large advantage.'

\#2: Percentage of respondents selecting either 'Very large benefit' or 'Fairly large benefit.'

\#3: Percentage of respondents selecting either 'Willing to do so out of our free will' or 'Willing to do so upon request.' 
future. The average satisfaction levels regarding these three outcomes need to be improved. At the same time, program managers should reduce the fluctuation regarding satisfaction with these evaluating items.

The ABC-G network makes great contributions to performance of the practical exercises. Especially, the relationship among academics (A), business persons (B), and consultants $(\mathrm{C})$ is vital. The teaching team for the practical exercises consists of $\mathrm{A}, \mathrm{B}$, and $\mathrm{C}$ members, each with unique competencies and values. The outcomes of practical sessions depend on their trust for the network. To develop trust among the network, members should sympathize with their values based on the swing model of enlightenment and learning process model for value co-creation shown in Figures 2 and 4. This is possible though identifying each member's interest and resources, and also promoting idea generation for developing rules for sympathy according to the empirical model shown in Figure 6. This approach is taken by social capital management (Halpern, 2005). The case indcates the one of model which is a successful example of a social capital usefullness of an education.

\subsubsection{Management system developed}

The following points are indicated to provide continuous development and improvement of management systems for educational programs through the experience of this case study.

1) Solutions to incomplete learning management system functions:

- Improve and maintain learner motivation after the completion of the program,

- Open up systems.

2) For overcoming the limitations of teaching methods concerning instructor-learner partnerships and their collaboration, implementation of the following measures to develop systems where instructors and learners can jointly embody the truth that 'teaching is learning':

- Public disclosure of good practices,

- Instructor training,

- Further development of IT-Jigs by co-creation with the collaboration with instructor and learner for group working based on learning process model for value co-creation shown in Figure 4.

\section{CONCLUSIONS}

This paper proposed a system model and analysed its application in a case study of the management system of an educational program for production managers in leadership roles who wish to create new market values by putting manufacturing technology to use through an ABC-G network. The basic concept combines an intelligent knowledge-based approach with a kaizen activity program within the framework of new value co-creation model under a symbiotic competition. At the same time, this concept has a learning process model based on the self- and mutual-enlightenment. The procedure of developing the educational program and its management system took a traditional approach of ADDIE model. It is hard to manage the kaizen activity according to a tacit knowledge of individual and/or organization. But the case of the development of learning program and educational management system based on the models mentioned above indicates the insight of value co-creation among the ABC-G network and a learner as production manager who has the competency of total optimization of some business processes and operations. Also the case shows an educational program based on self- and mutual-enlightenment on the basis of symbiotic competition within the system. Furthermore, the evaluation results of the program and the system show the effectiveness in pointing out the future problem for learning by working.

\section{REFERENCES}

Aikawa, A. (2012), Feeling Model: The Lecture Note of Leadership Management, Kanazawa Institute of Technology, Ishikawa, Japan.

Allen, M. W. (2003), Michael Allen's Guide to e-Learning: Building Interactive, Fun, and Effective Learning Programs for any Company, John Wiley and Sons, Hoboken, NJ.

Argyris, C. (1999), On Organizational Learning (2nd ed.), Blackwell Publishing, Oxford, UK.

Bersin, J. (2004), The Blended Learning Book: Best Practices, Proven Methodologies, and Lessons Learned, Pfeiffer, San Francisco, CA.

Brandenburger, A. M. and Nalebuff, B. J. (1996), Coopetition, Doubleday, New York, NY.

Drucker, P. F. (1993), Post-capitalist Society, Harper Business, New York, NY.

Halpern, D. (2005), Social Capital, Polity Press, Cambridge, UK.

Inose, H. (2000), To search an ideal of the world based on the symbiotic competitiveness concept, Technology and Economy, 1(404), 4-5.

Ishii, K. and Nakano, M. (2009), IT educational tools (IT JIGS) for production planning and control, Proceedings of the 20th International Conference on Production Research (ICPR), Shanghai, China.

Ishii, K. and Tamaki, K. (2009), Automation in education/learning systems, In: Nof, S. Y. (ed.), Springer Handbook of Automation, Springer, Heidelberg, Germany, 1503-1527.

Japan Institute of Plant Maintenance (1996), TPM for Every Operator (Shopfloor Series), Productivity 
Press, Portland, OR.

Malhotra, Y. (2000), Knowledge Management and Virtual Organizations, Idea group Publishing, Hershey, PA.

Mizuno, S. (1969), Company-wide quality control activities in Japan, Reports of Statistical Application Research, 16(3), 68-77.

Mogensen, A. H. (1932), Common Sense Applied to Motion and Time Study, McGraw-Hill, New York, NY.

Nonaka, I. and Takeuchi, H. (1995), The KnowledgeCreating Company: How Japanese Companies Create the Dynamics of Innovation, Oxford University Press, New York, NY.

Paine, L. S. (2003), Value Shift: Why Companies Must Merge Social and Financial Imperatives to Achieve Superior Performance, McGraw-Hill, New York, NY.

Payne, A. F., Storbacka, K., and Frow, P. (2008), Managing the co-creation of value, Journal of the Academy of Marketing Science, 36(1), 83-96.

Piskurich, G. M. (1993), Self-Directed Learning: A Practical Guide to Design, Development, and Implementation, Jossey-Bass, San Francisco, CA.

Piskurich, G. M. (2000), Rapid Instructional Design: Learning ID Fast and Right, Jossey-Bass, San Francisco, CA.

Polanyi, M. and Sen, A. (1967), The Tacit Dimension, University of Chicago Press, Chicago, IL.

Prahalad, C. K. and Ramaswamy, V. (2004), The Future of Competition: Co-Creating Unique Value with Customers, Harvard Business School Pub., Boston, MA.

Rothwell, W. J. And Kazanas, H. C. (1998), Mastering the Instructional Design Process: A Systematic Approach (2nd ed.), Jossey-Bass, San Francisco, CA.

Ryder, M. (2014), Instructional Design Models, http:// carbon.ucdenver.edu/ mryder/itc/idmodels.html.

Seybold, P. B., Lewis, J. M., and Marshak, R. (2001), The Customer Revolution, Random House, New York, NY.

Sheikh, K. (2003), Manufacturing Resource Planning (MRP II): with Introduction to ERP, SCM, and $C R M$, McGraw-Hill, New York, NY.

Smith, A. (1789), An Inquiry into the Nature and Causes of the Wealth of Nations (5th ed.), Thomas Dobson, Philadelphia, PA.

Spender, J. C. and Kijne, H. J. (1996), Scientific Management: Frederick Winslow Taylor's Gift to the World? Kluwer Academic Publishers, Boston, MA.

Sugimori, Y., Kusunoki, K., F. Cho, F., and Uchikawa, S. (1977), Toyota production system and Kanban system Materialization of just-in-time and respectfor-human system, International Journal of Production Research, 15(6), 553-564.

Taylor, F. W. (1911), The Principles of Scientific Management, Harper and Brothers, New York, NY.

Toffler, A. and Toffler, H. (2006), Revolutionary Wealth, Currency/Doubleday, New York, NY. 